\title{
Education Finance in Egypt: Problems and a Possible Solution
}

F. Henry Healey, Luis Crouch, and Rafik Hanna

January 2014 


\section{About the Authors} education scientist in RTI's International Development Group.

Luis Crouch, $\mathrm{PhD}$, is a senior economist in RTI's International Development

Group.

Rafik Hanna, BA, served as education decentralization specialist for the United States Agency for International Development's (USAID's) Girls' Improved Learning Outcomes Project in Cairo, Egypt.
F. Henry Healey, PhD, is a senior

RTI Press publication OP-0017-1401

RTI International is an independent, nonprofit research organization dedicated to improving the human condition. The RTI Press mission is to disseminate information about RTI research, analytic tools, and technical expertise to a national and international audience. RTI Press publications are peer-reviewed by at least two independent substantive experts and one or more Press editors.

\section{Suggested Citation}

Healey, F. H., Crouch, L., \& Hanna, R. (2014). Education finance in Egypt: Problems and a possible solution (RTI Press publication OP-0017-1401). Research Triangle Park, NC: RTI Press.

(C)2014 Research Triangle Institute. RTI International is a registered trademark and a trade name of Research Triangle Institute. The RTI logo is a registered trademark of Research Triangle Institute.

Research Triangle Park, NC

27709-2194 USA

Tel: $\quad+1.919 .541 .6000$

Fax: $\quad+1.919 .541 .5985$

E-mail: rtipress@rti.org

Website: www.rti.org
This publication is part of the Research Report series. Occasiona

RTI International

3040 East Cornwallis Road

PO Box 12194
(C) $\$$ Th $\$$ NC ND
Attribution-NonCommercial-NoDerivatives 4.0 license (CC BY-NC-ND),
a copy of which is available at https://creativecommons.org/licenses/ by-nc-nd/4.0/legalcode. 


\section{Education Finance in Egypt: Problems and a Possible Solution}

\section{F. Henry Healey, Luis Crouch, and Rafik Hanna}

\section{Contents}

Background and Problem

Statement

The Extent of the Inequity

Problem

The Tilt Toward "Remote" Governorates

The Nutrition Line Item

The Impact of Poverty

The Impact of Population Density

Compensation for Internal Inequity?

Are Allocations Unstable Over Time?

Local Awareness of Inequity

Winners and Losers

Potential Solution A "Hold Harmless" Approach

5

5

7

7

7

9

10

10

Conclusions and Policy Implications

Bibliography

Acknowledgments Inside back cover

moving from the MOF to the muderiyat, education offices at the governorate level of the system. Analysis of these latter allocations reveals that they are highly inequitable on an inter-governorate per-student basis, ranging from EGP 966 per student in New Valley to EGP 25 per student in 6th of October. This paper examines the nature and potential causes of this inequity and espouses a way in which these funds could be transferred using an equity-based funding formula that holds harmless those muderiyat that would lose absolute amounts of money under such a more equitable distribution scheme. 


\section{Background and Problem Statement}

Unrelated to the current political changes brought on by the Arab Spring movements, Egypt had started to make a number of significant strides in the use of enrollment- and poverty-based funding formulas. As shown in Table 1, increasing amounts of money had been transferred to lower levels of the system, with EGP 8.46 million $^{1}$ being decentralized to three pilot muderiyat ${ }^{2}$ in 2008/09, and EGP 575 million being decentralized nationwide in 2011/12 following

1 EGP: Egyptian pound. EGP $1=\$ 0.17$ at the time of the analysis

2 Muderiyat (plural form of muderiya) are governorate-level education departments. The governorate is the first subnational level, similar to states or provinces in other countries-but noting that Egypt is not a federal country. similar equity-based principles. ${ }^{3}$ We evaluated each of these occasions in which government funds were passed down to lower levels of the system. The overwhelming response to the effort was positive among all the key stakeholders surveyed: parental members of the Boards of Trustees, principals, Idara Heads, and Muderiya Heads (Healey, Hana, \& Atalla, 2012a, 2012b; Healey, Crouch, \& Hana, 2009, 2010).

3 Egypt's governmental financial accounting separates finances according to BABs, which are "chapters" or, literally, "gates." BAB2 refers to nonpersonnel recurrent expenditure, including both minor and major maintenance. BAB6 refers to capital expenditures.

\section{Table 1. Recent enrollment- and poverty-based funding formula efforts in Egypt}

\begin{tabular}{|c|c|c|c|}
\hline Fiscal Year & $\begin{array}{l}\text { Type of money } \\
\text { transferred }\end{array}$ & $\begin{array}{l}\text { Amount } \\
\text { (EGP) }\end{array}$ & Pathway \\
\hline 2008/09 & $\begin{array}{l}\text { MOE's non-personnel } \\
\text { BAB2 }\end{array}$ & $8.46 \mathrm{M}$ & $\begin{array}{l}\text { Money went directly from the MOE to all schools in the pilot } \\
\text { muderiyat of Fayoum, Ismailia, and Luxor. }\end{array}$ \\
\hline $2009 / 10$ & MOE's BAB2 & $10.1 \mathrm{M}$ & $\begin{array}{l}\text { Money went directly from the MOE to all schools in the pilot } \\
\text { muderiyat of Fayoum, Ismailia, and Luxor. }\end{array}$ \\
\hline \multirow[t]{3}{*}{$2010 / 11$} & $\begin{array}{l}\text { GAEB's BAB2 for } \\
\text { Maintenance }\end{array}$ & $210 \mathrm{M}$ & $\begin{array}{l}\text { Money went directly from the MOF to every muderiya in } \\
\text { the country. } 105 \mathrm{M} \text { eventually went to government schools } \\
\text { nationwide for minor maintenance; } 105 \mathrm{M} \text { stayed at the muderiya } \\
\text { to address major maintenance needs of some schools (an amount } \\
\text { too difficult to distribute by formula). }\end{array}$ \\
\hline & $\begin{array}{l}\text { MOE's BAB2 for One } \\
\text { Classroom Schools, } \\
\text { Technical Schools, and } \\
\text { Nutrition }\end{array}$ & $15.17 \mathrm{M}$ & $\begin{array}{l}\text { Money went directly from the MOF to every muderiya in the } \\
\text { country. } 5 \mathrm{M} \text { went to every Technical School nationwide; } 4 \mathrm{M} \text { went } \\
\text { to every One Classroom school nationwide; and } 6.17 \mathrm{M} \text { stayed at } \\
\text { the muderiya to support their respective nutrition programs. }\end{array}$ \\
\hline & $\begin{array}{l}\text { MOE's BAB6 for Technical } \\
\text { Schools' Operations and } \\
\text { Technical Education } \\
\text { Reform }\end{array}$ & $224 M$ & $\begin{array}{l}\text { Money went directly from the investment bank to every muderiya } \\
\text { in the country. The muderiyat developed plans to improve the } \\
\text { overall condition of those technical schools most in need. }\end{array}$ \\
\hline \multirow[t]{3}{*}{$2011 / 12$} & $\begin{array}{l}\text { GAEB's BAB2 for } \\
\text { Maintenance }\end{array}$ & $210 M$ & Same as $2010 / 11$ \\
\hline & $\begin{array}{l}\text { MOE's BAB2 for One } \\
\text { Classroom Schools, } \\
\text { Technical Schools, and } \\
\text { Nutrition }\end{array}$ & $15.17 \mathrm{M}$ & Same as $2010 / 11$ \\
\hline & $\begin{array}{l}\text { MOE's BAB6 for Technical } \\
\text { Schools' Operations and } \\
\text { Technical Education } \\
\text { Reform }\end{array}$ & $350 M$ & Same as $2010 / 11$ \\
\hline
\end{tabular}

$\mathrm{BAB} 2$ = recurrent expenditures; $\mathrm{BAB6}=$ capital expenditures; $\mathrm{GAEB}=$ General Authority for Education Buildings; $\mathrm{MOE}=$ Ministry of Education; MOF $=$ Ministry of Finance.

Source: Created by the authors on the basis of key Government of Egypt memoranda and policy documents. 
These efforts have been characterized by several features that, in the Egyptian context, are quite innovative. These features, described below, allow the allocation of this expenditure to be called "decentralized."4 First, the funding is allocated to lower levels of the system via simple and transparent equity-based funding formulas. Accordingly, all actors can know how much is being allocated to themselves, to others, and why. Moreover, because the allocation is done by such a funding formula, it minimizes budgetary transaction costs and obviates a long-standing negotiation practice that has resulted in grossly inequitable per-student allocations across governorates.

Second, the decentralized education finance approach that has been unfolding since 2007 allocates money in such a way as to allow the recipients some discretion in how to use the money: what to purchase, when, and from whom. However, it must be noted that these processes are not yet ideal in that, for instance, in the BAB6 allocations there are certain restrictions on the use of the funding - a large percentage can be used only for technical schools. ${ }^{5}$ Nevertheless, it is a meaningful beginning toward what many would refer to as decentralized education finance (Hill \& Bonan, 1991; Ross \& Levacic, 1999; Kim, 2008; Uyttersprott, 2008; Healey \& Crouch, 2012).

While this paper does not focus on advocating for decentralization, or examining its pros and cons in any detail, it does take two claims as its point of departure: (1) that decentralization is an existing trend in many countries and is a policy option that many international agencies urge countries to at least consider (Smoke, 2000, 2001; Basher, 2003; Busemeyer 2012; Ahmad, Brosio, \& Tanzi, 2005), and that (2) if a country is likely to embark upon

\footnotetext{
4 Movement of government resources from the center to a subnational level of the system does not, in and of itself, constitute what the literature would refer to as decentralized finance (Hill \& Bonan, 1991; Ross \& Levacic, 1999; Kim, 2008; Uyttersprott, 2008; Healey \& Crouch, 2012).

5 Also, when the BAB2 allocation went nationwide, the maintenance line item of EGP 210M from the General Authority for Education Buildings (GAEB) was used. The procurement law requires that this maintenance money cannot be transferred between line items, but schools can choose from among a very large list of minor maintenance activities. While far from perfect, this approach does give schools some element of choice over an issue-minor maintenance-on which they are bestinformed and thus can make swift and information-based decisions.
}

some form of decentralization, the design of the mechanisms for decentralization ought to take into account their efficiency and equity impacts (Monk, 1990; Augenblick, Meyers, \& Anderson, 1997; Roza \& Miles, 2002; Sharma, 2005; Kim, 2008; Odden \& Picus, 2008; Ahmad \& Brosio, 2009; Healey \& Crouch, 2012). On the assumption that post-reform Egypt will continue decentralization efforts, an analysis of past modalities of transferring funds (particularly in terms of equity) is timely and justified.

The efforts carried out so far, as detailed in Table 1, used equity-based formulas, as is generally recommended in the literature (Monk, 1990; Berne \& Steifel, 1994; Odden \& Busch, 1998; Ladd, Chalk, \& Hansen, 1999; Roza \& Miles, 2002; Paqueo, LopezAcevedo, \& Parandekar, 2003). Depending on whose advice future Egyptian authorities seek and heed, it is possible that the authorities would attempt to continue with some form of equity-oriented formula. But a major problem with decentralizing existing funds via an equity-based formula is this: If, in the past, the funding was distributed without a strong implicit formula or some other rationale acceptable in the public discourse of a democratizing nation, and if it was highly inequitable in per capita terms across governorates, then introducing a formula that provides funding on a conventionally rational and more equitable basis can produce strong winners and losers.

While the winners would be quite pleased with the situation, the losers would probably not be, and they would likely tether their misfortune not to the fact that they have been opaquely privileged in the past but to the introduction of decentralization and formula-based funding. This could give decentralization and formula funding a bad name and so make the overall effort that much more difficult to implement, when in fact decentralization and formula-based funding have many positive aspects (e.g., horizontal accountability, customer satisfaction, equity, transparency, predictability, low transactions costs).

There are of course many pros and cons to decentralization. The literature on this issue is vast (Rondinelli, Nellis, \& Cheema, 1983; Hannaway \& 
Carnoy, 1993; Naidoo, 2002; Faguet, 2004; Ahmad, Devarajan, Khemani, \& Shah, 2005; De Grauwe et al., 2005; Sharma, 2005; Winkler, 2005; Kim, 2008; Ahmad \& Brosio, 2009; Healey \& Crouch, 2012). A summary of the pros and cons is beyond the scope of this paper. The paper assumes, instead, that countries embark on decentralization for many very complex reasons, not all of them necessarily "rational" from a "modernist" or technocratic point of view. The paper assumes, nonetheless, along with the literature, that once a decentralization path is chosen, the mechanisms for doing so should attempt to maximize equity and efficiency (Rondinelli et al., 1983; Hill \& Bonan, 1991; Litvack, Ahmad, \& Bird, 1998; Welsh \& McGinn, 1999; Winkler, 2005; Kim, 2008; Healey \& Crouch, 2012).

One particular feature of the decentralized education finance process that has unfolded thus far, which has made it relatively easy to introduce, is the fact that the resources that have been transferred to the subnational units of the education system were traditionally allocated directly to the center, either to the central MOE, or Diwan, or to the General Authority for Education Buildings (GAEB) at the national level. Once there, these funds were generally spent by the Diwan/GAEB on behalf of the subnational units, purchasing goods and services and then transferring those goods to, and carrying out those services in, the subnational units. This means that the subnational units had very little perception of the cash value of what they were getting, much less the per-student values of those goods and services. Moreover, in some cases the funding represented temporary efforts to boost spending in a particular subsector of the education system (e.g., technical education reform). Given these two factors, equitybased formula funding has been relatively easy to introduce, in that, because it is perceived as "new" money, it has not created any strong sense of winners and losers among the subnational units. ${ }^{6}$ That the funding appears as fresh money that has been equitably distributed decreases a sense of winners and losers and thus provides an ideal way to demonstrate

6 However, there have been clear losers in the center, in particular, those units whose funds have been transferred to lower levels of government as part of decentralization. These units naturally would tend to resist a reduction in their power to make important financial decisions. how one can transfer resources as cash and according to an equity-oriented formula.

However, the amount of non-personnel recurrent money that is shown in Table 1 to have been decentralized via an equity-based funding formula is a small portion of the total amount of BAB2 resources that subnational units-in particular, the muderiyathave been receiving each year. Table 2 shows that the muderiyat have been getting approximately 40 percent of the total amount of BAB2 directly from the MOF. Though the table does not show it, this has been the case for quite some time. ${ }^{7}$

Table 2. Shares of key expenditure categories by level of government (fiscal year 2009/10)

\begin{tabular}{l|c|c|c|c} 
& \multicolumn{2}{|c|}{ BAB2 } & \multicolumn{2}{c}{ BAB6 } \\
\cline { 2 - 6 } Level & $\begin{array}{c}\text { Amount } \\
\text { (EGP) }\end{array}$ & $\begin{array}{c}\text { Share } \\
(\%)\end{array}$ & $\begin{array}{c}\text { Amount } \\
\text { (EGP) }\end{array}$ & $\begin{array}{c}\text { Share } \\
(\%)\end{array}$ \\
\hline Center & $1,568,004,000$ & 54 & $1,672,517,000$ & 88 \\
\hline Muderiyat & $1,207,463,000$ & 42 & $224,000,000$ & 12 \\
\hline Schools & $120,170,000$ & 4 & NA & - \\
\hline Total & $2,895,637,000$ & 100 & $1,896,517,000$ & 100 \\
\hline
\end{tabular}

$\mathrm{BAB} 2$ = recurrent expenditures; $\mathrm{BAB6}=$ capital expenditures; $\mathrm{NA}=$ not applicable.

Source: Created by the authors on the basis of key Government of Egypt memoranda and policy documents.

The problem here is that the particular subset of $\mathrm{BAB} 2$ resources that this table refers to has largely been allocated on the basis of history, negotiation, and a number of heretofore unknown factors that have resulted in a highly inequitable inter-governorate perstudent allocation, as shown in Table 3. Given the size of this inequity, the introduction of an equity-based funding formula would surely produce considerable winners and losers. When the losers become aware of the change, they would then tend to blame the formula funding itself. This would be unfortunate, as any likely publicly transparent formula is likely to be an equity and efficiency improvement over past ad hoc allocations. (Ad hoc allocations, of course, have a political-economic or at least a bureaucratic-inertia logic and in that sense may be "rational." But they are not rational in a manner that is easy to publicly

\footnotetext{
7 The authors know this from discussions with key people in the Government of Egypt, people who know how the budgeting and financing processes have worked.
} 
defend in a democratizing situation.) Thus, if there is a possibility that Egypt will deepen decentralization efforts in the future and is likely to try to decentralize finances using an equity-based funding formula, it is important to explore the extent and nature of the inequities in funding and to propose a way in which these funds can be more equitably distributed without causing much undue political fallout.

The remainder of this paper attempts to carry out the above tasks in several steps. The first step is to evaluate whether there is an implicit formula (or set of formulas) underlying current allocations, and whether that implicit formula, if made explicit, would likely fulfill the transparency and accountability needs of a democratizing situation. This step consists of two aspects. The first is to correlate the spending levels, by muderiya, with as many possible policy motivations as seems reasonable to see whether the correlations have implicit patterns. The second aspect is to interview key informants to assess whether they are even aware of inter-muderiya differences in per capita allocations and, if so, whether they can articulate the rationale for the differences.

A second step is to determine whether the allocations, if inequitable, are somewhat stable over time. If so, expectations are likely to have emerged that they will continue, thus rendering a reform toward equity and efficiency more difficult. The third and final step is-if no implicit formula is discovered in the current allocations, or if the implicit formula is likely unacceptable in a democratizing situation (e.g., if the funding is implicitly pro-rich) - to propose a formula and a means to introduce the formula that would minimize the political fallout by protecting the losers to the degree possible.

\section{The Extent of the Inequity Problem}

As noted, the first step in the analysis is to show that there is an inequity in the allocations and then to try to see whether that inequity responds to some implicit formula that could survive public scrutiny in a decentralization situation. This section starts the process by documenting the inequity issue.
The extent of the inequity problem raised in the Introduction is shown in Table 3 (following page) in the column labeled Total BAB2/student, which shows the per-student values of the BAB2 funding that were already being channeled to the muderiyat directly from MOF. Those values range from EGP 966 per student in New Valley to EGP 25 per student in 6th of October. This is an enormous gap, higher than that which prevailed, for instance, in South Africa, in the difference between African and white schools, toward the end of apartheid. It is difficult to think of a rationale that could possibly account for the fact that some muderiyat get upwards of over 38 times more money, on a per-student basis, than others. But there may be a certain rationale that could explain at least part of the difference.

\section{The Tilt Toward "Remote" Governorates}

Having established the fact of inequity, it then makes sense to try to understand whether the inequity follows some kind of logic that, in a transition toward a reformist Egypt, could withstand public scrutiny. It becomes apparent that the inequity tends to favor what Egypt classifies as the "remote" governorates-those that are distant from Cairo. This became even more evident when we looked at the line item labeled Allowances for Personnel Working in Remote Areas and observed how large that line item was, where that money was going, and how well the per-student values for these allowances correlated with the per-student allocations for the whole of BAB2 $(r=0.975) .8$ When these allowances were factored out of the overall per-student calculations, the spread between highest and lowest per-student values dropped from EGP 966-EGP 25 to EGP 243EGP 24-a drop of nearly 4 to 1 . Clearly, this one line item helps to account for and explain a good bit of the inequity shown in Table 3, because it makes sense that remote governorates should receive incentive money to attract staff members to work there. The "weight" given to remoteness might thus be publicly defensible if it were included in a transparent formula.

\footnotetext{
8 This correlation is calculated and asserted not as a partial or weak step in attributing causality but as a shorthand way of simply saying that the two are measuring essentially the same thing: the two variables convey basically the same information.
} 
Table 3. Breakdown of BAB2 finances by governorate
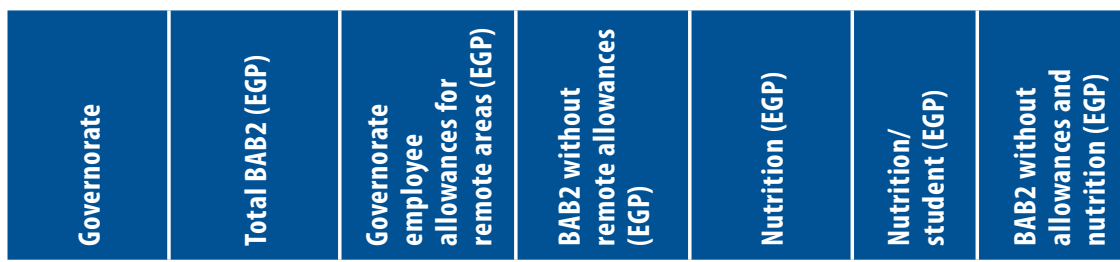

6th of

$12,984,000$

600,000

$12,384,000$

$5,615,000$

9.43

$6,769,000$

Alexandria $\quad 38,145,000$

$8,000,000 \quad 30,145,000$

$8,784,000$

$9.81 \quad 21,361,000$

$31,302,000$

$8,092,000$

22.22

$13,210,000$

Aswan

$10,478,000$

$23,980,000$

$34,755,000$

Bani Suef $\quad 38,622,000$

Beheira

$38,276,000$

$65,732,000$

0

0

Cairo

$52,010,000$

130,000

Dakahlia

$37,975,000$

Damietta $\quad 20,578,000$

Fayoum 32,050,000

Gharbia $22,981,000$

Giza $\quad 23,323,000$

Helwan $\quad 10,416,000$

Ismailia

Kafr el-

Sheikh

\begin{tabular}{|c|c|c|c|c|c|c|c|c|c|c|c|}
\hline Luxor & $23,958,000$ & $18,574,000$ & $5,384,000$ & $2,488,000$ & 24.33 & $2,896,000$ & 96,208 & 249 & 56 & 30 & 5,382 \\
\hline Mattrouh & $24,095,000$ & $8,200,000$ & $15,895,000$ & $12,562,000$ & 154.88 & $3,333,000$ & 78,867 & 306 & 202 & 42 & 6,329 \\
\hline Menofia & $34,347,000$ & 5,000 & $34,342,000$ & $17,060,000$ & 23.66 & $17,282,000$ & 693,825 & 50 & 49 & 25 & 6,799 \\
\hline Minia & $44,754,000$ & 0 & $44,754,000$ & $27,035,000$ & 26.38 & $17,719,000$ & 973,518 & 46 & 46 & 18 & 6,823 \\
\hline New Valley & $43,745,000$ & $33,500,000$ & $10,245,000$ & $7,069,000$ & 156.09 & $3,176,000$ & 45,289 & 966 & 226 & 70 & 7,358 \\
\hline North Sinai & $23,423,000$ & $8,000,000$ & $15,423,000$ & $9,700,000$ & 116.91 & $5,723,000$ & 81,011 & 289 & 190 & 71 & 5,668 \\
\hline Port Said & $10,078,000$ & 0 & $10,078,000$ & $5,927,000$ & 51.44 & $4,151,000$ & 104,927 & 96 & 96 & 40 & 6,823 \\
\hline Qalubia & $31,700,000$ & 0 & $31,700,000$ & $15,343,000$ & 16.24 & $16,357,000$ & 880,748 & 36 & 36 & 19 & 6,154 \\
\hline Qena & $150,380,00$ & $123,480,000$ & $26,900,000$ & $13,277,000$ & 19.19 & $13,623,000$ & 683,370 & 220 & 39 & 20 & 5,543 \\
\hline Red Sea & $30,162,000$ & $20,700,000$ & $9,462,000$ & $6,762,000$ & 123.36 & $2,700,000$ & 50,579 & 596 & 187 & 53 & 6,583 \\
\hline Sharqia & $59,837,000$ & 0 & $59,837,000$ & $19,175,000$ & 16.79 & $40,662,000$ & $1,117,204$ & 54 & 54 & 36 & 6,614 \\
\hline South Sinai & $6,922,000$ & $3,000,000$ & $3,922,000$ & $2,128,000$ & 127.47 & $1,794,000$ & 16,152 & 429 & 243 & 111 & 5,668 \\
\hline Suez & $6,524,000$ & 0 & $6,524,000$ & $2,265,000$ & 17.23 & $4,259,000$ & 118,438 & 55 & 55 & 36 & 6,254 \\
\hline Suhag & $98,660,000$ & $64,326,000$ & $34,334,000$ & $21,500,000$ & 25.27 & $12,834,000$ & 824,249 & 120 & 42 & 16 & 5,370 \\
\hline \multicolumn{8}{|c|}{ Weighted average } & 75 & 49 & 25 & 6,378 \\
\hline \multicolumn{8}{|c|}{ Standard deviation (weighted) } & 88.7 & 27.1 & 21.4 & 736.3 \\
\hline \multicolumn{8}{|c|}{ Average deviation (weighted) } & 47.1 & 14.4 & 11.9 & 619.2 \\
\hline \multicolumn{8}{|c|}{ Coefficient of variation 1} & 1.2 & 0.6 & 0.6 & 0.1 \\
\hline \multicolumn{8}{|c|}{ Coefficient of variation 2} & 0.6 & 0.3 & 0.3 & 0.1 \\
\hline \multicolumn{8}{|c|}{$\begin{array}{l}\text { Correlation of BAB2 per student, BAB2 minus allowances per student, and BAB2 minus allowances and } \\
\text { nutrition per student with GDP per capita }\end{array}$} & 0.07 & 0.04 & -0.02 & \\
\hline \multicolumn{8}{|c|}{$\begin{array}{l}\text { Correlation of BAB2 per student, allowances per student, and nutrition expenditure per student } \\
\text { with GDP per capita }\end{array}$} & 0.07 & 0.07 & 0.06 & \\
\hline
\end{tabular}

Source: Created by the authors from budgetary records of the Government of Egypt. 
Nevertheless, a large amount of inequity remains, by a factor of 10 to 1 EGP per student from most-financed to least-financed governorates.

\section{The Nutrition Line Item}

Might the remaining inequity also be publicly defensible? Another large line item that correlates fairly well with per-student allocations for the whole of BAB2 $(r=0.717)$ and that can account for a good bit of the inequity shown in Table 3 is Nutrition. When we took both the remote allowances and the nutrition line items out of the per-student calculations, the spread between highest and lowest per-student BAB2 allocation dropped to EGP 111EGP 13. But while the nutrition line item can help to account for a good bit of the inequity found in Table 3 in a purely correlational sense, it is not clear how well it can explain it in a more causal sense.

While the unit cost of the nutrition program will certainly be higher in the remote governorates than it is in the non-remote governorates, it is difficult to understand how a governorate such as New Valley should have been getting over 17 times more nutrition money per student than Gharbia, purely because of unit cost differences. Moreover, there are a number of anomalies, such as the nutrition per student values for Bani Suef and Qena. Why would the former, a nonremote governorate, get 2.4 times more for nutrition per student than the latter, which is a remote governorate? Could it be that these allocations (and allocations in general) were in some way factoring in poverty?

\section{The Impact of Poverty}

A look at the summary data provided at the bottom of Table 3 may help shed some light on this issue. Shown are the mean, or average, expenditure, as well as the two coefficients of variation (deviation divided by the average) for some of these factors. The standard deviation tends to exaggerate the bigger deviations (because it is the average of the square of the differences from any case to the mean), whereas the average deviation shows how much each case deviates from the average. Thus, average expenditure, after taking out the remote allowances, is about EGP 49 per student, but the average deviation from that average is a fairly large EGP 14.

Several factors stand out. First, the variation in expenditure is much higher-perhaps by a factor of 6 -than the variation in GDP per capita. This might be justified, to some extent, if the variation in expenditure were compensating for poverty, thus giving more money to the poorer governorates. But this is not the case. The table shows in the last two rows the correlation between expenditure and GDP per capita, which is essentially zero-around 0.05 or thereabouts. The first correlation expenditure row shows the correlation between each coefficient and GDP per capita - that is, the correlation of total BAB2 per student, BAB2 without allowances (per student), and $\mathrm{BAB} 2$ without allowances and nutrition (per student) with GDP per capita. The second correlation expenditure row shows the correlation between the expenditure on each given item - that is, BAB2 per student, allowances per student, and nutrition per student-and GDP per capita. In short, expenditure neither exacerbates nor compensates for poverty, at least as measured by the GDP per capita. Thus, poverty is not a meaningful implicit factor in these non-formula allocations.

\section{The Impact of Population Density}

We also considered the extent to which population density could account for the inequity shown in Table 3. The data in Table 4 show the relationship between population density and the BAB2 perstudent allocations. While the very most sparsely populated governorates (the top 5 or so) tended to get the highest $\mathrm{BAB} 2$ allocations per student, the overall correlation between population density and BAB2 per-student allocation is very low $(-0.142$ [not shown]). Moreover, it is important to decompose the budget in an attempt to identify the factors that can account for the higher per-student allocations and to see whether these factors typically apply only to the most sparsely populated governorates. Again, the interest here is to see how much apparent publicly defensible rationality there might be in the allocation. 


\begin{tabular}{|c|c|c|}
\hline Governorate & $\begin{array}{l}\text { Population } \\
\text { density }\end{array}$ & $\begin{array}{c}\text { BAB2 per } \\
\text { student (EGP) }\end{array}$ \\
\hline New Valley & 1 & 966 \\
\hline Red Sea & 1 & 596 \\
\hline Mattrouh & 2 & 306 \\
\hline South Sinai & 5 & 429 \\
\hline North Sinai & 12 & 289 \\
\hline 6th of October* & 14 & 25 \\
\hline Suez & 29 & 55 \\
\hline Aswan & 34 & 406 \\
\hline Helwan* & 43 & 30 \\
\hline Giza & 74 & 48 \\
\hline Minia & 129 & 46 \\
\hline Assiut & 133 & 71 \\
\hline Beheira & 468 & 38 \\
\hline Ismailia & 654 & 65 \\
\hline Kafr el-Sheikh & 762 & 33 \\
\hline Sharqia & 1,278 & 54 \\
\hline Fayoum & 1,375 & 57 \\
\hline Dakahlia & 1,436 & 38 \\
\hline Alexandria & 1,534 & 53 \\
\hline Qena & 1,622 & 220 \\
\hline Bani Suef & 1,733 & 68 \\
\hline Damietta & 1,855 & 83 \\
\hline Gharbia & 2,065 & 30 \\
\hline Menofia & 2,135 & 50 \\
\hline Suhag & 2,422 & 120 \\
\hline Qalubia & 4,233 & 36 \\
\hline Port Said & 7,927 & 96 \\
\hline Luxor & 8,206 & 249 \\
\hline Cairo & 36,386 & 53 \\
\hline
\end{tabular}

* The population density figures for 6 th of October and Helwan are estimates. Source: Created by the authors from population and budgetary records of the Government of Egypt.

Table 5 shows the per-student allocations of some line items that appear to correlate with population density. As one can see, there is generally not much correlation within the non-dense governorates for at least some of these items, so it is clear that they are not driven by any clear formula that accounts for population sparseness. For example, Mattrouh stands out as having small transportation costs in spite of being very sparsely populated. Nutrition expenditure appears to have been higher in the sparsely populated governorates, but then Damietta and Bani Suef, which are not sparsely populated, seem to have received relatively high nutrition allocations as well. And while the remoteness allowances correlate with sparseness, there are some very interesting outliers such as 6th of October and Luxor. And so, there still

Table 5. Specific per-student allocations compared with population density

\begin{tabular}{|c|c|c|c|c|c|}
\hline Governorate & 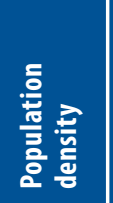 & 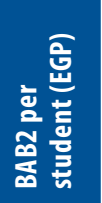 & 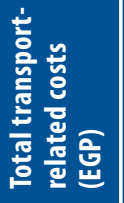 & 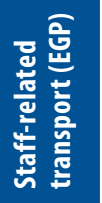 & 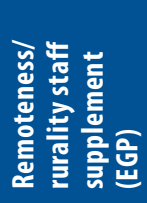 \\
\hline New Valley & 0 & 156 & 18 & 14 & 740 \\
\hline Red Sea & 1 & 134 & 15 & 11 & 409 \\
\hline Mattrouh & 2 & 159 & 8 & 6 & 104 \\
\hline South Sinai & 5 & 132 & 38 & 23 & 186 \\
\hline North Sinai & 12 & 120 & 26 & 21 & 99 \\
\hline $\begin{array}{l}\text { 6th of } \\
\text { October* }\end{array}$ & 14 & 11 & 1 & 1 & 1 \\
\hline Suez & 29 & 19 & 3 & 3 & 0 \\
\hline Aswan & 34 & 99 & 12 & 12 & 265 \\
\hline Helwan* & 43 & 9 & 1 & 1 & 0 \\
\hline Giza & 74 & 19 & 5 & 5 & 0 \\
\hline Minia & 129 & 28 & 3 & 3 & 0 \\
\hline Assiut & 133 & 23 & 3 & 3 & 31 \\
\hline Beheira & 468 & 17 & 3 & 3 & 0 \\
\hline Ismailia & 654 & 29 & 7 & 6 & 1 \\
\hline $\begin{array}{l}\text { Kafr } \\
\text { el-Sheikh }\end{array}$ & 762 & 10 & 4 & 3 & 0 \\
\hline Sharqia & 1,278 & 17 & 4 & 4 & 0 \\
\hline Fayoum & 1,375 & 39 & 4 & 3 & 0 \\
\hline Dakahlia & 1,436 & 12 & 4 & 3 & 0 \\
\hline Alexandria & 1,534 & 12 & 2 & 2 & 11 \\
\hline Qena & 1,622 & 19 & 4 & 4 & 181 \\
\hline Bani Suef & 1,733 & 46 & 2 & 1 & 0 \\
\hline Damietta & 1,855 & 52 & 5 & 4 & 0 \\
\hline Gharbia & 2,065 & 9 & 4 & 4 & 0 \\
\hline Menofia & 2,135 & 25 & 3 & 3 & 0 \\
\hline Suhag & 2,422 & 26 & 4 & 4 & 78 \\
\hline Qalubia & 4,233 & 17 & 2 & 2 & 0 \\
\hline Port Said & 7,927 & 56 & 4 & 3 & 0 \\
\hline Luxor & 8,206 & 26 & 7 & 7 & 193 \\
\hline Cairo & 36,386 & 17 & 1 & 1 & 0 \\
\hline
\end{tabular}

* The population density figures for 6th of October and Helwan are estimates. Source: Created by the authors from budgetary records of the Government of Egypt. 
is a great degree of unaccounted-for variability in the allocation. Population density, in other words, is also not a meaningful implicit factor in these nonformula allocations.

\section{Compensation for Internal Inequity?}

It was hypothesized that some of the differences in funding could be related to one of three further factors: (1) poverty rates, (2) percentage of population that is rural, or (3) internal inequity. All of these, if they are in fact important implicit factors in the allocations, would survive being made explicit. Note that some of these could be proxies for each other, or correlated. The hypothesis guiding this principle is that perhaps a political-economic consideration (though most likely an implicit one) is that governorates need to be subsidized to control the levels of inequity internal to them. This would have a clear logic and appeal. Consider two governorates that are otherwise equal with regard to GDP per capita, say, but one of which is more unequal, internally, than the other. Since inequity and social frustration are more likely to operate at the local level, it seems reasonable to try to create social stability by subsidizing subnational governments whose internal inequalities are high, so that they can take care of these issues.

However, no significant correlation was found between any of these factors and the spending per student, no matter how the spending was classified, except in the opposite of the direction one would hope, as shown in Table 6. The correlations that are statistically significant at the 5 percent level are highlighted with bold font. Naturally, the expenditure categories are correlated with each other; one would expect that. But as shown in the first column, the main expenditure category-Total BAB2 allocationis not significantly correlated with any important variable, except that it is positively correlated with the Human Development Index (HDI): the better-off governorates get more funding. Reading across the HDI row, one can see that the better-off governorates get more funding in every category.

A couple correlations are interesting for their own sake: (1) the higher the HDI, the greater the internal inequity, which means the more developed governorates are also the more unequal; and

\section{Table 6. Cross-governorate correlations, all factors}

\begin{tabular}{|c|c|c|c|c|c|c|c|c|c|c|}
\hline & 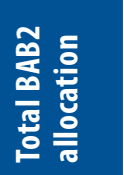 & 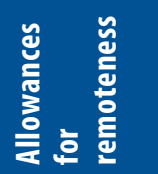 & 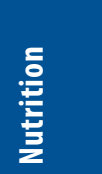 & 흥 & 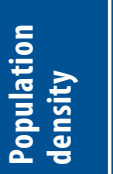 & 호용 & 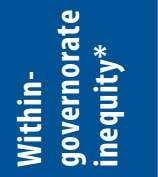 & 륭 옹 & 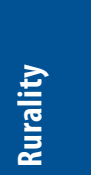 & 모 \\
\hline Total BAB2 & 1.00 & & & & & & & & & \\
\hline $\begin{array}{l}\text { Allowances for } \\
\text { remoteness }\end{array}$ & 0.98 & 1.00 & & & & & & & & \\
\hline Nutrition & 0.84 & 0.71 & 1.00 & & & & & & & \\
\hline Transportation & 0.67 & 0.54 & 0.76 & 1.00 & & & & & & \\
\hline $\begin{array}{l}\text { Population } \\
\text { density }\end{array}$ & -0.14 & -0.13 & --0.18 & -0.20 & & & & & & \\
\hline GDP per capita & 0.07 & 0.07 & 0.06 & -0.13 & -0.06 & 1.00 & & & & \\
\hline $\begin{array}{l}\text { Within- } \\
\text { governorate } \\
\text { inequity* }\end{array}$ & 0.09 & 0.08 & 0.07 & 0.05 & 0.08 & 0.01 & 1.00 & & & \\
\hline Poverty rate & 0.10 & 0.16 & 0.04 & -0.11 & -0.25 & -0.17 & -0.31 & 1.00 & & \\
\hline Rurality & -0.20 & -0.13 & -0.29 & -0.16 & -0.37 & 0.18 & -0.54 & 0.52 & 1.00 & \\
\hline HDI & 0.43 & 0.37 & 0.39 & 0.46 & 0.13 & 0.25 & 0.50 & -0.67 & -0.66 & 1.00 \\
\hline
\end{tabular}

* Measured as the standard deviation of GDP per capita across the various districts of each governorate. $\mathrm{HDI}=$ Human Development Index.

Note: Expense items refer to per-student expense. Bold indicates correlations that are statistically significant at the 5 percent level. Source: Analysis carried out by the authors. 
(2) the more rural governorates have less internal inequity, also a logical result. In summary, there is no meaningful pattern to the data, except in undesirable directions. This continues the line of evidence: There is no apparent implicit conventional (publicly defensible) rationality in the non-formula funding. In fact the only rationality or pattern found is least likely to be publicly defensible since it is anti-poor.

\section{Are Allocations Unstable Over Time?}

We have seen that the allocations do not obey implicit factors that could be put publicly defensibly and explicitly in a formula. But if these allocations have been highly unstable over time, then introducing a formula in which there were winners and losers would not alarm anyone, largely because no one would have developed a sense of entitlement or expectation. Unfortunately, this has not been the case. In fact, since the allocations appear to be based on history (i.e., muderiyat receive more or less what they got the year before plus a percentage increase), they are quite stable, with the correlation between governorates' allocations (that is, the correlation of total BAB2 allocation between governorates) in the two most recent years being 0.99-extremely stable. Moreover, the within-governorate correlation between the allocations to individual items averaged 0.99 . Thus, while these allocations are random with respect to need, they are highly stable over time, so one would expect that a sense of entitlement has developed-in fact, more than a sense: one would expect specific interest groups to be associated with these lines of expenditure within the governorates that have been, somewhat randomly (or based purely on negotiating power and political considerations), more favored in the past.

\section{Local Awareness of Inequity}

The analyses above reflect our attempts to use data and correlational analysis to discover whether there are any patterns in the allocations that, if uncovered, could become explicit and publicly defensible factors in a formula, and also, if there seem to be no such factors, to see whether the allocations are stable and are likely to have created expectations. We find that there appear to be no clear patterns causing the differences in allocations, but that the differences in allocations are stable over time and are therefore likely to have created expectations.

However, it is possible to round out the statistical analysis with more direct questioning of key informants. We carried out an informal field investigation in order to get a sense of muderiyat officials' cognizance of many of the issues raised in this paper. Our approach was to ask a number of questions of muderiya officials in two governorates that had relatively high per-student allocations (South Sinai and Aswan). In general, muderiya staff persons were not aware of how their muderiya ranked in terms of per-student expenditure, as compared with other muderiyat. Even in cases where a muderiya was receiving multiple times more per student than another muderiya, staff were generally unaware of these inter-muderiya differences which, to an analyst looking at the data, are striking. When we told staff persons of the inequalities, they were typically unable to give reasons as to why the disparities existed, other than some rather circular reasoning such as nutrition expenses being higher because more food is supplied. In some simple instances, however, staff persons were able to offer an explanation, such as high transport costs in South Sinai. Thus, in general, staff seemed to be unable to explain differences-which somewhat (though only somewhat; maybe staff simply are not aware of the reasons, and the fact that they were not aware of the differences in per capita allocations between muderiyat suggests that they would also not be aware of why those differences exist) confirms the statistical analysis that finds no conventionally rational explanation for the differences.

Staff persons who were involved in the general budgeting process negotiated with the MOF in isolation from their peers and colleagues in the other governorates and the MOE. This is one factor that could explain the lack of comparative unit cost awareness. It also means that budgeting tends to be unguided by national priorities. In fact, the only people who possessed ready access to comparative 
data were those in the national MOF, but these data do not seem to have had much currency, even there.

However, though unaware of how their own muderiya stood in relation to others in terms of per-student allocations, staff persons were quite aware of their yearly total budgeting and the budget for various line items. Their records were meticulous. Accordingly, introducing an equity-based funding formula that produces losers could be quite problematic, unless done in a no-harm manner. It is interesting to note that, as we discovered, in some cases line items were higher than what the muderiyat negotiated for, and in other cases lower, and in neither case could the staff adequately explain why this occurred. It suggests a very ad hoc budgetary process and suggests that current allocations are a stable and long-term accretion of ad hoc decisions, which the statistical analysis already suggested (with the exception of the allocation to "remote" muderiyat, though, again, the disaggregation of these allocations could not typically show why those muderiyat had higher allocations).

\section{Winners and Losers}

Given the apparent randomness shown in the analyses above (that is, given that the allocations do not respond to implicit factors that could be made explicit and publicly defensible), a logical policy recommendation is to suggest a formula that can make the funding more transparent and publicly defensible and that can base the funding on some measurable sense of equity and/or need, and then see what happens to the current allocations.

Table 7 shows the results of doing this. The column labeled EGP per student with funding formula shows what each muderiya would receive per student using such a formula. The last column shows the percentage difference between what each muderiya would get via this funding formula relative to what they actually received per student. Aswan, Mattrouh, New Valley, North Sinai, Red Sea, and South Sinai stand to be very big losers, losing up to 93 percent of what they were getting per student if a funding formula were to be introduced, illustrating the serious practical and political nature of the problem.
Table 7. Simulation of the impact of introducing a funding formula

\begin{tabular}{|c|c|c|c|c|c|}
\hline 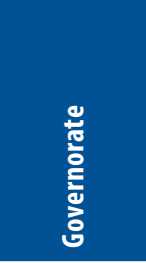 & 흘 & 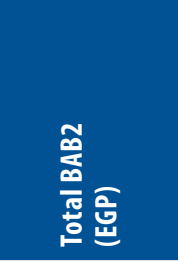 & 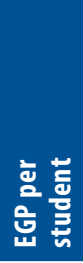 & 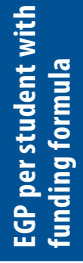 & 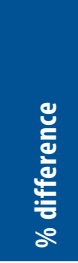 \\
\hline $\begin{array}{l}\text { 6th } \\
\text { October }\end{array}$ & 523,188 & $12,984,000$ & 25 & 77 & 2.06 \\
\hline Alexandria & 720,456 & $38,145,000$ & 53 & 68 & 0.28 \\
\hline Assiut & 782,210 & $55,282,000$ & 71 & 83 & 0.17 \\
\hline Aswan & 247,635 & $100,478,000$ & 406 & 70 & -0.83 \\
\hline Bani Suef & 566,962 & $38,622,000$ & 68 & 79 & 0.16 \\
\hline Beheira & $1,006,660$ & $38,276,000$ & 38 & 74 & 0.96 \\
\hline Cairo & 980,896 & $52,010,000$ & 53 & 68 & 0.29 \\
\hline Dakahlia & $1,011,325$ & $37,975,000$ & 38 & 72 & 0.89 \\
\hline Damietta & 247,477 & $20,578,000$ & 83 & 68 & -0.18 \\
\hline Fayoum & 559,451 & $32,050,000$ & 57 & 86 & 0.51 \\
\hline Gharbia & 758,869 & $22,981,000$ & 30 & 70 & 1.33 \\
\hline Giza & 485,647 & $23,323,000$ & 48 & 77 & 0.59 \\
\hline Helwan & 350,576 & $10,416,000$ & 30 & 68 & 1.27 \\
\hline Ismailia & 206,759 & $13,339,000$ & 65 & 69 & 0.07 \\
\hline $\begin{array}{l}\text { Kafr el- } \\
\text { Sheikh }\end{array}$ & 527,748 & $17,419,000$ & 33 & 78 & 1.37 \\
\hline Luxor & 96,208 & $23,958,000$ & 249 & 75 & -0.70 \\
\hline Mattrouh & 78,867 & $24,095,000$ & 306 & 76 & -0.75 \\
\hline Menofia & 693,825 & $34,347,000$ & 50 & 73 & 0.46 \\
\hline Minia & 973,518 & $44,754,000$ & 46 & 82 & 0.79 \\
\hline $\begin{array}{l}\text { New } \\
\text { Valley }\end{array}$ & 45,289 & $43,745,000$ & 966 & 65 & -0.93 \\
\hline $\begin{array}{l}\text { North } \\
\text { Sinai }\end{array}$ & 81,011 & $23,423,000$ & 289 & 72 & -0.75 \\
\hline Port Said & 104,927 & $10,078,000$ & 96 & 64 & -0.33 \\
\hline Qalubia & 880,748 & $31,700,0009$ & 36 & 72 & 1.00 \\
\hline Qena & 683,370 & $150,380,000$ & 220 & 78 & -0.65 \\
\hline Red Sea & 50,579 & $30,162,000$ & 596 & 60 & -0.90 \\
\hline Sharqia & $1,117,204$ & $59,837,000$ & 54 & 74 & 0.37 \\
\hline $\begin{array}{l}\text { South } \\
\text { Sinai }\end{array}$ & 16,152 & $6,922,000$ & 429 & 61 & -0.86 \\
\hline Suez & 118,438 & $6,524,000$ & 55 & 65 & 0.17 \\
\hline Suhag & 824,249 & $98,660,000$ & 120 & 82 & -0.32 \\
\hline
\end{tabular}

Note: The funding formula is enrollment- and Human Development Indexbased, with weights of 0.50 being given to both enrollment and poverty shares, as was done in the pilot in Fayoum, Ismailia, and Luxor. See Healey and Crouch (2009) for a description. Bold indicates governorates that lose the greatest percentage of funds.

Source: Analysis carried out by the authors using data from budgetary records of the Government of Egypt. 
Moreover, the situation does not really improve when the remoteness allowances and nutrition resources are taken out of the funding formula, as shown in
Table 8 . While the absence of these line items softens the extent to which the big losers lose, they still lose quite a bit-upwards of 80 percent.

Table 8. Impact of applying a funding formula to the BAB2 allocations minus the remoteness allowances and nutrition funding

\begin{tabular}{|c|c|c|c|c|c|c|}
\hline Governorate & 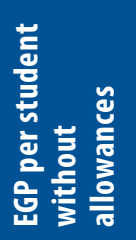 & 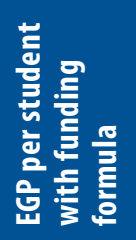 & 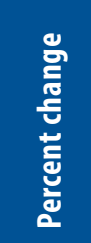 & 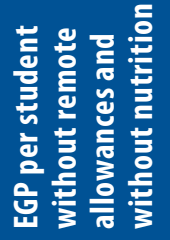 & 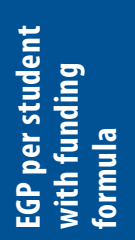 & 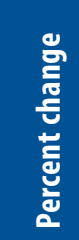 \\
\hline 6th of October & 24 & 50 & 1.08 & 13 & 22 & 0.69 \\
\hline Alexandria & 42 & 45 & 0.07 & 30 & 19 & -0.37 \\
\hline Assiut & 40 & 54 & 0.35 & 17 & 25 & 0.47 \\
\hline Aswan & 140 & 46 & -0.67 & 42 & 22 & -0.48 \\
\hline Bani Suef & 68 & 52 & -0.24 & 23 & 26 & 0.13 \\
\hline Beheira & 38 & 49 & 0.29 & 21 & 24 & 0.14 \\
\hline Cairo & 53 & 45 & -0.15 & 36 & 17 & -0.53 \\
\hline Dakahlia & 38 & 47 & 0.24 & 26 & 24 & -0.08 \\
\hline Damietta & 83 & 44 & -0.47 & 31 & 23 & -0.26 \\
\hline Fayoum & 57 & 56 & -0.02 & 19 & 26 & 0.37 \\
\hline Gharbia & 30 & 46 & 0.53 & 21 & 23 & 0.10 \\
\hline Giza & 48 & 50 & 0.04 & 29 & 18 & -0.38 \\
\hline Helwan & 30 & 45 & 0.50 & 21 & 20 & -0.05 \\
\hline Ismailia & 63 & 45 & -0.29 & 34 & 23 & -0.32 \\
\hline Kafr el-Sheikh & 33 & 51 & 0.55 & 23 & 25 & 0.09 \\
\hline Luxor & 56 & 49 & -0.13 & 30 & 24 & -0.20 \\
\hline Mattrouh & 202 & 50 & -0.75 & 42 & 25 & -0.40 \\
\hline Menofia & 49 & 48 & -0.02 & 25 & 24 & -0.04 \\
\hline Minia & 46 & 54 & 0.17 & 18 & 25 & 0.39 \\
\hline New Valley & 226 & 42 & -0.81 & 70 & 23 & -0.67 \\
\hline North Sinai & 190 & 47 & -0.75 & 71 & 24 & -0.66 \\
\hline Port Said & 96 & 42 & -0.56 & 40 & 21 & -0.48 \\
\hline Qalubia & 36 & 47 & 0.31 & 19 & 23 & 0.21 \\
\hline Qena & 39 & 51 & 0.31 & 20 & 25 & 0.25 \\
\hline Red Sea & 187 & 40 & -0.79 & 53 & 21 & -0.60 \\
\hline Sharqia & 54 & 49 & -0.09 & 36 & 24 & -0.33 \\
\hline South Sinai & 243 & 40 & -0.84 & 111 & 22 & -0.80 \\
\hline Suez & 55 & 42 & -0.24 & 36 & 21 & -0.42 \\
\hline Suhag & 42 & 54 & 0.29 & 16 & 25 & 0.56 \\
\hline
\end{tabular}

Note: In column 4, bold indicates the lower and upper ends of the range of EGP per student without allowances and without nutrition funding. Source: Created by the authors from budgetary records of the Government of Egypt. 
There seems to be a serious dilemma, then: traditional allocations are ad hoc and are not based on clear criteria that could be made explicit and be publicly defensible. But (not coincidentally) introducing a formula that is based on clear and transparent criteria that are likely to withstand public discourse would create big losers, who are likely to be opposed to the changes even if they can be shown to be in the national interest or can be shown to improve equity and efficiency.

\section{Potential Solution}

We have argued that the inequity problem highlighted in Table 3 is fairly serious and have just argued that, furthermore, allocating funds according to a more rational, population- and poverty-driven basis would create losers and might thus generate opposition.

However, we can argue, from a slightly different perspective, that the problem is not really that serious after all. Why? First, the majority of governorates with very high per-student funding are relatively small in absolute terms. Even if one counts all the governorates that would lose, it amounts to only 35 percent of total national student enrollment. If one counts only those governorates that would lose more than 25 percent of their funding, it is only 11 percent of enrollment. This means that even if their funding were admitted to be somewhat ad hoc, and they were held harmless (i.e., they would be guaranteed to receive allocations on a per-student basis that were not less than the per-student allocation they had received the year before), holding them harmless would not affect the implementation of the proposed solution much. Furthermore, not all of the losers would lose by a lot. In this sense, crafting a solution may not be as difficult as it seemed at first.

\section{A "Hold Harmless" Approach}

Table 9 shows the results of using an enrollment- and poverty-based funding formula to distribute BAB2 resources while holding harmless those governorates that would lose on a total-allocation basis. The data in Table 9 (following page) reflect a 1 percent annual increase in enrollment and a 15 percent increase in the budget (due to both GDP growth and inflation). ${ }^{9}$ The amount of BAB2 that has been distributed by this funding formula excludes the remote allowances but includes the nutrition line item and the additional EGP 210M that has been allocated to the muderiyat for maintenance referenced in Table 1.

The table shows only the amount of money that we refer to as misallocated: those excess resources needed to hold harmless the governorates that would lose money if they were to receive what the funding formula would allocate to them. If these governorates were held harmless, they would receive in absolute terms what they received in 2010 until such time that the amount of money that they received from the funding formula was greater (in nominal terms) than what they received in 2010. At that point, they would factor into the funding formula distribution scheme along with all the rest of the non-loser governorates.

In Table 9, the total amount of misallocated money amounts to 11.67 percent in 2010. Within two years this number drops to 5 percent of the total money being allocated, and in another four years it drops to a mere 1 percent. So, while the inequity problem that needs to be solved is indeed egregious, it appears that it can be fairly easily solved if one takes time into account and uses both growth and inflation to soften the impact on the erstwhile-privileged muderiyat.

9 The paper was written at a time when both growth and inflation were fairly high. After the current political turmoil, growth has slowed down, but inflation appears to have risen. It may still be possible to carry out the nominal hold-harmless approach suggested here, due to the higher inflation. A low-inflation, low-growth scenario, though, should it materialize, would make the approach difficult to implement as quickly as suggested here, and may take twice as long. 
Table 9. Misallocated BAB2 funding (in EGP) when all funding losers are held harmless with the introduction of an enrollment- and poverty-based funding formula

\begin{tabular}{|c|c|c|c|c|c|c|c|c|c|c|c|c|}
\hline Governorate & 2010 & 2011 & 2012 & 2013 & 2014 & 2015 & 2016 & 2017 & 2018 & 2019 & 2020 & 2021 \\
\hline 6th of October & 0 & 0 & 0 & 0 & 0 & 0 & 0 & 0 & 0 & 0 & 0 & 0 \\
\hline Alexandria & 0 & 0 & 0 & 0 & 0 & 0 & 0 & 0 & 0 & 0 & 0 & 0 \\
\hline Assiut & 0 & 0 & 0 & 0 & 0 & 0 & 0 & 0 & 0 & 0 & 0 & 0 \\
\hline Aswan & $22,979,687$ & $20,701,081$ & $18,080,683$ & $15,067,226$ & $11,601,751$ & $7,616,454$ & $3,033,363$ & 0 & 0 & 0 & 0 & 0 \\
\hline Bani Suef & $10,069,118$ & $4,543,933$ & 0 & 0 & 0 & 0 & 0 & 0 & 0 & 0 & 0 & 0 \\
\hline Beheira & 0 & 0 & 0 & 0 & 0 & 0 & 0 & 0 & 0 & 0 & 0 & 0 \\
\hline Cairo & $5,952,028$ & 0 & 0 & 0 & 0 & 0 & 0 & 0 & 0 & 0 & 0 & 0 \\
\hline Dakahlia & 0 & 0 & 0 & 0 & 0 & 0 & 0 & 0 & 0 & 0 & 0 & 0 \\
\hline Damietta & $8,999,865$ & $6,759,414$ & $4,182,895$ & $1,219,898$ & 0 & 0 & 0 & 0 & 0 & 0 & 0 & 0 \\
\hline Fayoum & $2,541,463$ & 0 & 0 & 0 & 0 & 0 & 0 & 0 & 0 & 0 & 0 & 0 \\
\hline Gharbia & 0 & 0 & 0 & 0 & 0 & 0 & 0 & 0 & 0 & 0 & 0 & 0 \\
\hline Giza & 0 & 0 & 0 & 0 & 0 & 0 & 0 & 0 & 0 & 0 & 0 & 0 \\
\hline Helwan & 0 & 0 & 0 & 0 & 0 & 0 & 0 & 0 & 0 & 0 & 0 & 0 \\
\hline Ismailia & $3,335,205$ & $1,442,939$ & 0 & 0 & 0 & 0 & 0 & 0 & 0 & 0 & 0 & 0 \\
\hline Kafr el-Sheikh & 0 & 0 & 0 & 0 & 0 & 0 & 0 & 0 & 0 & 0 & 0 & 0 \\
\hline Luxor & 661,739 & 0 & 0 & 0 & 0 & 0 & 0 & 0 & 0 & 0 & 0 & 0 \\
\hline Mattrouh & $11,983,607$ & $11,226,725$ & $10,356,310$ & $9,355,333$ & $8,204,210$ & $6,880,418$ & $5,358,058$ & $3,607,343$ & $1,594,021$ & 0 & 0 & 0 \\
\hline Menofia & 699,961 & 0 & 0 & 0 & 0 & 0 & 0 & 0 & 0 & 0 & 0 & 0 \\
\hline Minia & 0 & 0 & 0 & 0 & 0 & 0 & 0 & 0 & 0 & 0 & 0 & 0 \\
\hline New Valley & $8,172,447$ & $7,771,393$ & $7,310,182$ & $6,779,788$ & $6,169,836$ & $5,468,390$ & $4,661,728$ & $3,734,066$ & $2,667,256$ & $1,440,423$ & 29,566 & 0 \\
\hline North Sinai & $11,522,550$ & $10,767,785$ & $9,899,806$ & $8,901,629$ & $7,753,726$ & $6,433,638$ & $4,915,537$ & $3,169,720$ & $1,162,031$ & 0 & 0 & 0 \\
\hline Port Said & $5,294,113$ & $4,368,397$ & $3,303,824$ & $2,079,564$ & 671,666 & 0 & 0 & 0 & 0 & 0 & 0 & 0 \\
\hline Qalubia & 0 & 0 & 0 & 0 & 0 & 0 & 0 & 0 & 0 & 0 & 0 & 0 \\
\hline Qena & 0 & 0 & 0 & 0 & 0 & 0 & 0 & 0 & 0 & 0 & 0 & 0 \\
\hline Red Sea & $7,216,274$ & $6,781,710$ & $6,281,962$ & $5,707,251$ & $5,046,334$ & $4,286,279$ & $3,412,216$ & $2,407,044$ & $1,251,095$ & 0 & 0 & 0 \\
\hline Sharqia & $5,285,710$ & 0 & 0 & 0 & 0 & 0 & 0 & 0 & 0 & 0 & 0 & 0 \\
\hline South Sinai & $3,203,470$ & $3,064,429$ & $2,904,533$ & $2,720,651$ & $2,509,188$ & $2,266,005$ & $1,986,345$ & $1,664,735$ & $1,294,884$ & 869,556 & 380,428 & 0 \\
\hline Suez & $1,103,941$ & 55,122 & 0 & 0 & 0 & 0 & 0 & 0 & 0 & 0 & 0 & 0 \\
\hline Suhag & 0 & 0 & 0 & 0 & 0 & 0 & 0 & 0 & 0 & 0 & 0 & 0 \\
\hline Total & $109,021,179$ & $77,482,929$ & $62,320,194$ & $51,831,343$ & $41,956,711$ & $32,951,185$ & $23,367,246$ & $14,582,908$ & $7,969,287$ & $2,309,979$ & 409,994 & 0 \\
\hline \% Budget & $11.67 \%$ & $7.21 \%$ & $5.05 \%$ & $3.65 \%$ & $2.57 \%$ & $1.75 \%$ & $1.08 \%$ & $0.59 \%$ & $0.28 \%$ & $0.07 \%$ & $0.01 \%$ & $0.00 \%$ \\
\hline
\end{tabular}




\section{Conclusions and Policy Implications}

In the period leading up to the Arab Spring, Egypt had already embarked on decentralization of certain expenditures using an equity-based, pro-poor, highly transparent funding formula. This experiment showed that it is indeed possible (technically and politically) to allocate funds in this manner, and stakeholder reaction to the new way of transferring funds was overwhelmingly positive. Other important education expenditures (such as personnel costs and a large portion of non-personnel recurrent costs) had already for many years been transferred to the muderiyat, but using no clear formula or allocation criteria. This paper shows that non-personnel recurrent allocations were extremely unequal, with per-student allocations in some muderiyat being hundreds of times greater than per-student allocations in other muderiyat. When such funds are allocated in such an inequitable manner, and there is no clear reason for doing so, those jurisdictions that receive more money per student are greatly advantaged over those that receive less money per student.

This inequitable distribution of funds is the product of a constellation of factors. The formal government budgeting process is driven largely by a bottom-up accumulation of wish lists. Lower-level jurisdictions are asked by their higher-level counterparts for an estimate of the resources they need in the upcoming year. Since need always outstrips available resources, these wish lists result in exaggerated and incoherent budgets. With these figures in hand, muderiya authorities negotiate with the MOF for the resources they allegedly need. Those who can negotiate better have an obvious advantage over those who cannot. Once the budget is passed by parliament, some approximation of what was requested and negotiated finds its way down to lower-level jurisdictions. Clearly, equity-based formula funding does not factor into the budget-finance cycle at all.

Per-student funding need not be equal. Vertical equity arguments maintain that on a per-student basis, poor jurisdictions should get more than less poor jurisdictions. And if in rural jurisdictions it costs more to do and/or buy certain things, then that would lead to a higher per-student allocation than in jurisdictions where these things are not so expensive. The analyses performed in this paper show that while some of the inequitable allocation can be explained (e.g., allowances for personnel working in remote regions of the country), much cannot. As a result, the children in those jurisdictions where the per-student allocations are low simply aren't as educationally well-served as those students in jurisdictions where the per-student allocations are inexplicably high. In a modernizing Egypt (the hopeful outcome of the Arab Spring) these per-student allocations would need to become a lot more equitable and to the extent they are not the same, viable reasons must account for it.

Short of overhauling the entire budgeting and financing process in Egypt, a topic for another paper, a logical solution to this problem would be to allocate funds according to the successful experimental equity-based formula described in the paper. However, a simulated allocation of these traditional allocations according to the new, experimental formula, showed that many muderiyat would be losers (by logic, about half would get less money than they had been getting per student) in the reallocation, which could lead to a negative political reaction against the use of transparent equity-based formulas for allocating funds. Further simulations show that if one assumes a reasonable amount of economic growth and some inflation, these losing muderiyat would receive allocations per student that were at least the same as the per-student allocation they had received the year before (i.e., be held harmless), thus making it politically palpable and thus possible to introduce equity-based formula funding over several years.

Given the profoundly political-economic nature of such changes, however, even when the losses are "nominal" and could be absorbed over a few years, a very deliberative approach will be required. A considerable amount of policy dialogue, experimentation, mobilization of the opinion of those with a favorable impression from the formula-based experiment, would all be required. Once the current tensions are hopefully over, Egypt has options in moving towards a fairer and more efficient way to allocate its education funds. 


\section{Bibliography}

Ahmad, E., \& Brosio, G. (Eds). (2009). Does decentralization enhance service delivery and poverty reduction? Northampton, MA: Edward Elgar Publishing Inc.

Ahmad, E., Brosio, G., \& Tanzi, V. (2005). Local service provision in selected OECD countries: Do decentralized operations work better? (IMF Working Paper No. WP/08/67). Washington, DC: International Monetary Fund.

Ahmad, J., Devarajan, S., Khemani, S., \& Shah S. (2005). Decentralization and service delivery (Policy research working paper 2603). Washington, DC: World Bank.

Annenberg Institute for School Reform. (2010). Voices in urban education: Student-based budgeting, 29 (Fall). Providence, RI: Brown University. Retrieved March 29, 2013, from http://annenberginstitute.org/sites/default/files/ product/198/files/VUE29.pdf

Archer, J. (2004). 'Weighted' funding of schools gains favor. Education Week, 24(10), 1, 20-21.

Augenblick, J. G., Meyers, J. L., \& Anderson, A. B. (1997). Equity and adequacy in school funding. Financing Schools, 7(3), 63-78.

Baker, B. D. (2009). Within-district resource allocation and the marginal costs of providing equal educational opportunity: Evidence from Texas and Ohio. Education Policy Analysis Archives, 17(3), 1-27. Retrieved March 29, 2013, from http://epaa.asu.edu/ojs/article/view/5/5

Baker, B. D., Sciarra, D. G., \& Farrie, D. (2010). Is school funding fair? A national report card. Newark, NJ: Education Law Center.

Basher, S. A. (2003). Fiscal decentralization in developing countries: A review of current concepts and practice (review). The Journal of Developing Areas, 37(1), 178-179.

Berne, R., \& Steifel, L. (1994). Measuring equity at the school level: The finance perspective. Education Evaluation and Policy Analysis, 16(4), 405-421.
Bossert, T. J., Larranaga, O., Giedion, U., Arbelaez, J. J., \& Bowser, D. M. (2003). Decentralization and equity of resource allocation: Evidence from Colombia and Chile. Bulletin of the World Health Organization, 81(2), 95-100.

Busemeyer, M. (2012, April). Two decades of decentralization in education governance: Lessons learned and future outlook for local stakeholders. Presentation at the OECD conference on Effective Governance on the Local Level. Warsaw, Poland. Retrieved from http://www.oecd.org/edu/ ceri/50293543.pdf

De Grauwe, A., Lugaz, C., Baldé, D., Diakhaté, C., Dougnon, D. Moustapha, M., \& Odushina, D. (2005). Does decentralization lead to school improvement? Findings and lessons from research in West-Africa. Journal of Education for International Development, 1(1). Retrieved from http://www.equip123.net/JEID/articles/1/1-1.pdf

Education Resource Strategies. (2010). Fair student funding summit: Conference proceedings and recommendations for action. Watertown, MA: Education Resource Strategies.

Faguet, J. P . (2004). Does decentralization increase government responsiveness to local needs? Evidence from Bolivia. Journal of Public Economics $88,867-893$.

Hadderman, M. (1999). Equity and adequacy in educational finance (Report number EDOEA-99-5). ERIC Digest, 129. Eugene, OR: ERIC Clearinghouse on Educational Management, University of Oregon.

Hannaway, J., \& Carnoy, M. (eds). (1993).

Decentralization and school improvement: Can we fulfill the promise? Consortium for Policy Research. San Francisco, CA: Jossey-Bass.

Healey, F. H., \& Crouch, L. (2012). Decentralization for high-quality education: Elements and issues of design (RTI Press publication No. OP-0008-1208). Research Triangle Park, NC: RTI Press. Retrieved from http://www.rti.org/rtipress. doi:10.3768/ rtipress.2012.op.0008.1208. 
Healey, F. H., Hanna, R., \& Attalla, M.H. (2012a). Final evaluation report: Decentralized education finance in Egypt 2011/12. Prepared for the Girls' Improved Learning Outcomes (GILO) project. Cairo, Egypt: United States Agency for International Development.

Healey, F. H., Hanna, R., \& Attalla, M. H. (2012b). Final evaluation report: Decentralized education finance in Egypt 2010/11. Prepared for the Girls' Improved Learning Outcomes (GILO) project. Cairo, Egypt: United States Agency for International Development.

Healey, F. H., Crouch, L., \& Hanna, R. (2010). Final evaluation report: Decentralized education finance pilots in Egypt 2009/10. Prepared for the Girls' Improved Learning Outcomes (GILO) project. Cairo, Egypt: United States Agency for International Development.

Healey, F. H., Crouch, L., \& Hanna, R. (2009). Final evaluation report: Decentralized education finance pilots in Egypt 2008/09. Prepared for the Girls' Improved Learning Outcomes (GILO) project. Cairo, Egypt: United States Agency for International Development.

Healey, F. H., \& Crouch, L. (2009). Final report on the 2008/09 pilots: Decentralized education finance in Fayoum, Ismailia, and Luxor. Prepared for the Girls' Improved Learning Outcomes (GILO) project. Cairo, Egypt: United States Agency for International Development.

Hill, P., \& Bonan, J. (1991). Decentralization and accountability in public education. Santa Monica, CA: Rand Corporation.

Hoxby, C. (2001). All school finance equalizations are not created equal. Quarterly Journal of Economics, 116(4), 1189-1231.

Kim, A. (2008). Decentralization and the provision of public services (World Bank Policy Research Working Paper 4503). Washington, DC: World Bank.

Ko, W. A. (2006). The impact of new funding formula on school finance equity in Missouri. Education, 126(3), 559-568.

Ladd, H., Chalk, R., \& Hansen, J. (1999). Equity and adequacy in education finance: Issues and perspectives. Washington, DC: National Academy Press.
Ladd, H. (2008). Reflections on equity, adequacy, and weighted student funding (Working Paper Series SAN08-04). Durham, NC: Sanford Institute of Public Policy, Duke University.

Ladd, H., \& Fiske, E. (2009). The Dutch experience with weighted student funding: Some lessons for the US (Working Paper Series SAN09-03). Durham, NC: Sanford School of Public Policy, Duke University.

Lefkowits, L. (2004). School finance: From equity to adequacy (McREL Policy Brief). Aurora, CO: MidContinent Research for Education and Learning.

Lewin, K., \& Caillods, F. (2001). Financing secondary education in developing countries: Strategies for sustainable growth. Paris: International Institute for Educational Planning.

Litvack, J., Ahmad, J., \& Bird, R. (1998). Rethinking decentralization in developing countries (Sector Studies Series \# 21492). Washington, DC: World Bank.

Monk, D. (1990). Education finance: An economic approach. New York: McGraw Hill.

Naidoo, J. P. (2002). Education decentralization in SubSaharan Africa-Espoused theories and theories in use. Paper presented at the 46th Annual Meeting of the Comparative and International Education Society, Orlando, Florida.

Needs-based resource allocation via formula funding of schools. (1999, April-June). IIEP Newsletter, $X V I I(2)$.

Odden, A., \& Busch, C. (1998). Financing schools for high performance. Strategies for improving the use of educational resources. San Francisco: Jossey-Bass.

Odden, A., \& Picus, L. O. (2008). School finance: A policy perspective. Boston: McGraw Hill.

Ouchi, W. G. (2003). Making schools work: A revolutionary plan to get your children the education they need. New York: Simon \& Schuster.

Paqueo, V., Lopez-Acevedo, G., \& Parandekar, S. (2003). On the use of transparent formulae to allocate federal education transfers (World Bank policy research working paper 3171). Washington, DC: World Bank. 
Picus, L. O., \& Odden, A. R. (2011). Reinventing school finance; falling forward. Peabody Journal of Education, 86, 291-303.

Psacharapoulos, G . J., Tan, P., \& Jimenez, E. (1986). Financing education in developing countries: An exploration of policy options. Washington, DC: World Bank.

Rechovsky, A. (1994). Fiscal equalization and school finance. National Tax Journal, 47(1), 185-97.

Rondinelli, D. A., Nellis, J. R., \& Cheema, G. S. (1983). Decentralization in developing counties: A review of recent experiences (World Bank staff working paper 581). Washington, DC: World Bank.

Ross, K., \& Levacic, R. (1999). Needs-based resources allocation in education via formula funding of schools. Paris: UNESCO International Institute for Education Planning.

Roza, M., Guin, K., \& Davis, T. (2008). What is the sum of the parts? How federal, state, and district funding streams confound efforts to address different student types. School Finance Redesign Project. Seattle, WA: Center on Reinventing Public Education, University of Washington.

Roza, M., \& Miles, K. H. (2002). Moving toward equity in school funding within districts: $A$ comparison of traditional funding policies and more equitable formulas. Prepared for: School Communities that Work: A National Task Force on the Future of Urban Districts. Providence, RI: Annenberg Institute for School Reform at Brown University.

Saavedra, J. (2002). Education financing in developing countries: Level and source of funds. Washington, DC: World Bank.

Shambaugh, L. S., Chambers, J. G., \& DeLancey, D. (2008). Implementation of the weighted student formula policy in San Francisco: A descriptive study of an equity-driven, student-based planning and budgeting policy (Issues \& Answers Report, REL 2008-No. 061). Washington, DC: US Department of Education, Institute of Education Sciences, National Center for Education Evaluation and Regional Assistance, Regional Educational Laboratory West.
Sharma, C. K. (2005). When does decentralization deliver? The dilemma of design (MPRA paper No. 250). Retrieved from http://mpra.ub.unimuenchen.de/250/

Smoke, P. (2000). Beyond normative models and development trends: Strategic design and implementation of decentralization in developing countries. Prepared for: Management Development and Governance Division. New York: United Nations Development Program.

Smoke, P. (2001). Fiscal decentralization in developing countries A review of current concepts and practice democracy, governance, and human rights. Programme paper number 2. Geneva: United Nations Research Institute for Social Development.

State of Rhode Island General Assembly. (2007). Funding our future: An approach to fund education in Rhode Island. Providence, RI: Rhode Island Public Expenditure Council.

Toutkoushian, R. K., \& Michael, R. S. (2007). An alternative approach to measuring horizontal and vertical equity in school funding. Journal of Education Finance, 32(4), 395-421.

Uyttersprot, I. (2008). Financing education in developing countries: New modalities, new approaches. Examples from Rwanda (Working Document). Paris: UNESCO International Institute for Educational Planning.

Welsh, T., \& McGinn, N. (1999). Decentralization of education: Why, when, what, and how? Paris, France: UNESCO International Institute for Educational Planning.

Winkler, D. (2005). Understanding decentralization (EQUIP 2 Policy Brief). Washington, DC: United States Agency for International Development.

Winkler, D. R., \& Schlegel, A. (2005). Education decentralization and school grants (EQUIP 2 Policy Brief). Washington, DC: United States Agency for International Development.

Wong, K. (1999). Funding public schools: Politics and policies. Lawrence, KS: University Press of Kansas. 


\section{Acknowledgments}

The authors would like to acknowledge the assistance and support of the United States Agency for International Development. 
RTI International RTI International is an independent, nonprofit research institute dedicated to improving the human condition. We combine scientific rigor and technical expertise in social and laboratory sciences, engineering, and international development to deliver solutions to the critical needs of clients worldwide. 